\title{
Market Democracy and Meaningful Work: A Reply to Critics
}

\author{
John Tomasi ${ }^{1}$
}

Published online: 20 November 2015

(C) The Author(s) 2015. This article is published with open access at Springerlink.com

I am grateful for the care and generosity with which the contributors to this symposium have engaged with Free Market Fairness. This collection of essays forced me to think, and to think again, about the foundations of market democracy. Each of the six contributors presents several (and often as many as five) discrete criticisms of market democracy. The level of analysis is so consistently high that every one of these myriad arguments merits a reply. However, attempting that would require a very long essay (and perhaps another book). So I shall focus here on what seem to me the central, or most challenging, objections each critic raises. To meet those objections, I often found myself forced to develop arguments that I merely sketched in Free Market Fairness. On some topics, most notably the idea of meaningful work, I have taken this opportunity to develop the market democratic framework in new directions: along with replying to specific objections, the market democratic ideal of meaningful work is the central theme of my reply.

Fowler sets out a host of challenging objections to market democracy. First, following a path blazed by Liam Murphy and Tom Nagel, Fowler argues that property rights, as legal conventions, come posterior to the tax code, and thus taxes cannot impede on property rights (Murphy and Nagel 2004; Tomasi 2012, pp. 69-72). Fowler offers a novel formulation of this idea: 'the proper distinction between natural rights theorists and conventional theorists is whether a property claim is an input into deciding which scheme of property laws to enforce or if it is purely an output of these laws'. He invites us to imaging a tribe living next to a single large berry bush, on which their survival depends. They consider various ownership-generating rules for gathering (each may pick and own as many berries

John Tomasi

john_tomasi@brown.edu

1 Brown University, Providence, RI, USA 
as they like; each may pick and own no more than 100 per day; etc.). In such a case, Fowler argues, claims of ownership arise wholly posterior the selection of the set of ownership-generating rules. For conventionalists, economic liberties are outputs of established systems of rules, not inputs that must be considered when deciding which system of rules to affirm. Accepting conventionalism about economic liberty, Fowler suggests, is unlike accepting conventionalism about, say, political liberty: 'This is because citizens have an individual claim to having a say in governance. This claim is theoretically prior to conventions.' Considerations of political liberty are inputs into decisions about which particular system of political liberty should be affirmed. Thus, a system which denies individual citizens the right to vote is unlike a system which denies them the right to own private property (say, by mandating collective ownership).

Like the argument by Murphy and Nagel, this argument from convention seeks to cut off moral arguments about the relative standing of economic and political liberties before they can get started. Like the attempt by Murphy and Nagel, however, Fowler's argument is circular. I agree that, pre-conventionally, citizens have a claim to participate in decisions about governance: political liberty is an input into decisions about what form of governance rules to conventionally affirm. Along with this, however, I claim that citizens have a claim to engage in independent economic activity: economic liberty is an input into decisions about which property rules to conventionally affirm. Regarding the tribe living near the berry bush, this input must be given weight when they set up their property rules, just as the claim of individuals to have a say in their governance must be.

Now, Fowler claims that economic liberty lacks the status as an input that economic liberty possesses. But on what basis can he assert this claim? He cannot simply stipulate that concerns about individual economic liberty are outputs rather than inputs in the context of conventionalism. For that would be to stipulate an answer to the very question we are asking. The only possible way to reach the conclusion Fowler prefers is by way of moral argument. There is no magic wand within the conventionalist framework that allows one to label some categories of claims 'inputs' and others 'outputs,' in a pattern that preserves some moral status quo of one's own liking. Fowler, like Murphy and Nagel, cannot cut off the moral argument simply by pointing down to our common conventionalist ground. In $F M F$, I provide a moral argument, based on the moral powers of self-authorship, that democratic citizens have powerful economic liberty interests, just as they have political ones. If Fowler wishes to show that economic liberties are mere outputs rather than inputs, then it is my substantive moral arguments that he must address. The choice between a conventionalist and a natural rights framework itself settles nothing about the moral priority of private economic liberty.

What about those substantive arguments? Fowler offers two arguments designed to weaken the link between private economic liberty and self-authorship. The first concerns what he calls 'valueless agency.' Even if the sort of market-society I defend does increase the range of economic choices available to citizens, Fowler argues, this need not foster self-authorship. In a market society, economic choices proliferate so as to produce a disorganized tangle, a 'spaghetti junction,' of options. The options spontaneously generated may not be attractive, and even if they are 
attractive people may not be competent to navigate those domains of choice. Thus, a market-generated proliferation of choices may not increase people's ability to exercise their powers as self-authors. For example, when American citizens were given control over certain categories of their retirement savings, studies suggest they lacked awareness of basic facts that greatly impact the performance of their retirement fund elections, such as what fees they were paying.

It is unclear to me whether Fowler means to be offering this argument on the level of ideal or non-ideal analysis. Whichever level he intends, note that he must choose one and stick to it when comparing market democratic and social democratic models (it is no good comparing ideal social democracy with non-ideal market democracy, for example).

At the level of ideal theory, I suppose market democratic and social democratic approaches to complex questions of healthcare and retirement planning both work out pretty well. On the market democratic side, market price mechanisms, free of the distortions from crony capitalism, bring together information about productive resources and about the preferences of citizens so as to generate an attractive array of options, along with encouraging a culture of personal responsibility (including economic literacy). On the social democratic side, political actors, free of the distortions charted by public choice theorists, consult an informed electorate and settle on collective schemes of healthcare and retirement provision that work well for all (sustainably across generations, etc.)

But if market democracy and social democracy reach a draw on the ideal theoretic question of the capacity of each to 'realize' (its own preferred interpretation of democratic justice), how do they not reach a draw when these issues are analyzed at the non-ideal level? After all, as Fowler writes: 'Many choices about healthcare, pensions and other services provided by social democratic states are highly complex and technical.' Is he imagining that citizens who do not know what fees they are paying on their retirement accounts will suddenly become literate when voting on these (vastly more complex) questions of economic policy? Many studies have shown that ordinary democratic citizens are uninformed and/or misinformed about economic policy issues (see Caplan 2007). But if, as a matter of non-ideal analysis, this weakens the connection of their political participation to their standing as self-authors, does this mean that we should curtail people's political liberties? Presumably not. ${ }^{1}$ But if we reject that conclusion, what reason has Fowler given for weakening the protection of their economic liberties, such as the ones I defend?

Clayton and Stevens offer an important challenge to my market democratic interpretation of the Difference Principle. I shall address that in a moment, but I first consider their critique of my proposal that a thick conception of economic liberty be recognized as among the basic liberties. Briefly, following H.L.A. Hart's famous critique of Rawls, Clayton and Stevens say that my proposal to 'expand' the list of basic liberties must be evaluated in terms of that expansion's effect on others using those same liberties. They argue that the cost of expanding the list of liberties,

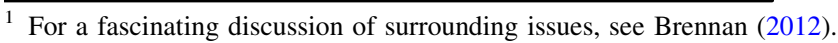


judged in terms of the exercise of like liberties by others, is prohibitively high: only a thin conception of economic liberty should be recognized as basic.

In reply, I note first that 'expansion' is not quite the correct (or relevant) term for my proposal for the recognition of thick economic liberty. After all, it is the high liberals who are advocating a contraction of the basic liberties, so as to exclude the thick conception of economic liberty widely affirmed by the (historically) classical liberal thinkers. I call this call for contraction the platform of economic exceptionalism - the thesis that economic liberties should be singled out from the traditional list for 'thinning down'-and I challenge high liberals to defend that platform by way of moral argument.

Put that terminological matter aside, though. Whether we call it 'contraction' or 'expansion,' the core project is to identify a fully adequate scheme of basic rights and liberties. Fully adequate to what? Fully adequate to the development and exercise of moral powers of self-authorship (the capacity to be a self-author, and the capacity to respect one's fellow citizens as self-authors too). Might there be intraliberty tensions as citizens go about acting on the various liberties we recognize as basic, whether those liberties be economic or, say, civil? Certainly. Imagine that we recognize freedoms of speech and association as among the basic liberties. An atheist couple raising their child in some heavily Christian area may find themselves driving by billboards, directed at children, promoting Christ as their savior. So too there may be tensions in the exercise of the thick economic liberties that I recommend as basic (though, as I argue in $F M F$, a characteristic feature of the exercise of private economic liberty, under favorable circumstances, is that the exercise of such liberties expands the opportunities of others to exercise their liberties of that sort).

As Clayton and Stevens are aware, however, Hart's critique was aimed at Rawls's early formulation of the set of basic rights and liberties, a formulation that appeared to call for the maximization of liberty. Under pressure from Hart's critique, Rawls later adjusted his view to the more 'sufficientarian' one I mention above: rather than identifying a set which maximizes liberty, Rawls took the approach of seeking to identify a set of liberties that, taken as a set, enable citizens to exercise their moral powers of citizenship. In arguing for the recognition of thick economic liberty, I follow the methodological path of the mature Rawls. However, I am aware that my formulations in Free Market Fairness were not always clear or consistent on this point (see von Platz 2013, pp. 1-22). Perhaps Clayton and Stevens read me as taking a maximizing approach to basic liberty, and roll out the Hart critique for that reason. If so, this was an error of exposition on my part.

More substantively, Clayton and Stevens offer a strong challenge to my interpretation of the Difference Principle. In $F M F$, following Phillipe van Parijs, I note that the Difference Principle is ambiguous: that principle requires that we affirm institutions that maximize advantages to the least fortune, but those 'advantages' are set out by a complex index of primary goods (what I call 'DPgoods') (van Parijs 2003, pp. 200-240). Some goods in the DP-index may be subject to scarcity such that we cannot maximize them all simultaneously. This need to make choices generates different interpretations of the Difference Principle. 
I use van Parijs to press a critique against thinkers such as Rawls who affirm what I call a social democratic interpretation of the distributive requirements of justice. Since Rawls affirms the Difference Principle, and since the DP-index includes wealth and income, many people believe that Rawls thinks that distributive justice requires that we affirm institutions that generate the greatest wealth and income to the least fortunate. ${ }^{2}$ But this cannot be right. For, along with committing himself to maximizing DP-goods to the least well-off, Rawls also says that slow or no-growth economic systems can realize justice as fairness. To square this exegetical circle, as I argue in $F M F$, social democrats such as Rawls must forgo the moral affirmation of institutions that aim to maximize the wealth of the least well off. By contrast, my market democratic interpretation of distributive justice affirms a commitment to maximizing the wealth personally controlled by the least fortunate members of society. This is a fundamental point of contrast between social democratic and market democratic conceptions of what we owe our fellow citizens. This contrast tells powerfully in favor of market democracy. For while market democracy, uniquely, seeks to maximize the wealth of the least fortunate over time, social democracy insists the concerns for the least fortunate be expressed in different terms: forgoing opportunities for provide greater wealth, they suggest that we show our respect for the least fortunate by setting them within democratically controlled places of work (Tomasi 2012, pp. 180-192).

Now, Clayton and Stevens challenge me on this important issue. They say that my democratic interpretation of the Difference Principle is overly narrow: it focuses on the moral importance of wealth to the exclusion of other more morally important DP-goods, such as positions of responsibility and the social bases of self-respect. They also see my view of work as excessively 'white-collar'. Capitalist firms are hierarchical. For those not working in executive suites, the experience of work is degrading. Indeed, Clayton and Stevens describe managers of capitalist firms as routinely confronting 'an unenthusiastic, unmotivated, and alienated workforce,' who are dissatisfied with 'management control and surveillance of worker behaviour.'

Given all this, Clayton and Stevens reject my market democratic interpretation of the Difference Principle, with its commitment to maximizing the wealth and income of the least fortune. Rather than wealth, they think democratic justice requires that we attend more to the lived experience of work. The worker-owned and managed firms of (ideal) liberal socialism and (ideal) property-owning democracy, with their steadfast commitment to collective decision-making, may well be outstripped by capitalist firms in terms of the production of social wealth (especially since, following the Mill-Keynes-Rawls line that I chart, they do not even aim at economic growth). But when assessing the complex index of primary goods,

\footnotetext{
2 I use 'wealth and income' as a short-hand to denotes the stock of material assets personally controlled by any representative member of the class of lowest paid workers. That measurement of that 'stock of material goods' would require that we consider the quantity and quantity of consumer goods that are available and obtainable by them. The relevant comparison, of course, is between the stocks of goods made available by rival regime types (as specified by rival conceptions of justice, social democratic and market democratic).
} 
maximizing wealth in not nearly as important as providing the opportunity for meaningful work.

I am delighted that Clayton and Stevens have raised this issue. Most critics of Free Market Fairness have focused on my arguments in favor of thick economic liberty. But the contrast I draw between market democratic and social democratic interpretations of distributive justice is just as important in showing the moral superiority of market democracy. So I welcome this opportunity to expand my argument in favor of the market democratic conception of work.

In a single passage, now infamous, Rawls rejects the idea of the democratic justice directs us to maximize the wealth and income of the lowest paid workers, insisting instead that we need merely provide them with a 'satisfactory minimum.' On this social democratic approach, we respect citizens when we organize our society, not so as to provide them with high salaries, but when we instead provide them with the forms of work made available in socialist communes or in the firms of property-owning democracy. While wealth may be a distraction or even a hindrance, Rawls tells us: 'What men really want is meaningful work in free association with others' (Rawls 1999, p. 257).

Now, in $F M F$, I do not claim that the market democracy affirms the absolute maximization of wealth and income over all the other components of the complex index of DP-goods. I simply contrast the market democratic approach, with the special weighting it gives to the importance of the lowest paid workers personally gaining wealth, against the social democratic approach, which insists that is more important to situate workers in democratic workplaces thus forgoing wealth. Let us revisit this issue.

In FMF, I implicitly accepted the social democratic terms of the debate, with greater wealth on the market democratic side, and meaningful work on the social democratic one. I now see this matter differently. While market democracy rightly (in my view) gives greater weight to wealth and income, there is no reason to accept the idea that the forms of work offered by social democratic ideals (collective ownership, democratic management by workers) has any special claim to the mantle of 'meaningful' work. Instead, what we have before us is another basic contrast that highlights the moral superiority of market democracy. For as social democracy carries within it a particular interpretation about what makes work meaningful, market democracy offers a rival interpretation of meaningful work.

Clayton and Stevens appear to imagine the organization of successful capitalist firms as rigidly hierarchical. Ronald Coase, writing in 1937, described firms as islands of socialism operating in a sea of calculative chaos-and those islands could indeed be organized 'hierarchically' (Coase 1937, pp. 386-405). Top-down forms of management (sometimes called 'command-and-control') were prevalent in the 1960s and 1970s. Firms organized that way routinely encountered 'principal-agent' problems, in which the aims of individual workers did not line up with the aims of managers. Principal-agent problems, in all their variety, do indeed threaten to result in the 'unenthusiastic, unmotivated, and alienated' workforce that Clayton and Stevens describe as typical of capitalism.

However, it is has been more then 50 years since Abraham Maslow published Maslow on Management, a book that revolutionized the management of capitalist 
firms (Maslow 1965). Based on Maslow's earlier work on the hierarchy of needs, management theory began to focus on the conditions in which workers within capitalist firms could find meaning in their daily work experiences. So hierarchical management is not definitive of the firms that exist, island-like, within market society. Coase, as I understand him, would agree: There is nothing about the need for islands that requires that those islands be organized hierarchically. On the contrary: capitalism itself generates pressures toward firm-diversity, a state of affairs in which rival organizational structures are constantly brought into competition with each other. A philosophically intriguing finding has emerged from this competition in recent years: speaking generally, firms that are the most thoroughly market-based in their management styles also tend to be the most successful in overcoming the principal-agent problem. Such firms also tend to make better use of local knowledge. (If rigid hierarchy worked, after all, what manager would have bothered to read Maslow?) Though I did not fully see this when I wrote $F M F$, I now believe that this process of firm management-selection in market society has an important normative implication: market democracy generates a distinctive account of the meaningfulness of work.

To outline the market democratic ideal of work, we need to dip into the recent psychological literature on happiness. ${ }^{3}$ Positive psychology, founded by Martin Seligman and Mihalyi Csikszentmihalyi in the 1990s, redirected psychological research from cataloging maladies toward a study of positive states of mental health, including happiness (Csikszentmihalyi 1997). The main finding of positive psychology is that it is more effective for people to focus on developing their strengths than on overcoming their weaknesses. While happiness does not seem to come from the possession of wealth alone, studies by psychologists such as Jonathan Haidt suggest that happiness, for most people, comes more from pursuing goals than achieving them (Haidt 2006). Csikszentmihalyi identified a state of mind that he called 'flow'. Flow, which denotes a kind of higher order happiness, is usually achieved when a person becomes totally immersed in a project that is challenging yet closely matched to their abilities. Strikingly, Csikszentmihalyi found that many of his subjects reported their work experiences as particularly salient sites of 'flow.' This is especially true among workers who 'see through' their work, not just to the goods of firm identity or personal affirmation of firm mission, but also through to the greater good for society that their work helps produce. ${ }^{4}$

In the workplace, the experience of flow was also correlated with the experience of occupational self-direction-the sense of individuals that they have personal control over workplace decisions about productivity. That sense of control occurs when a firm is organized in such a way that, when individuals find themselves

\footnotetext{
3 Psychologists typically do not distinguish between dimensions of 'meaningfulness,' of 'happiness,' and of 'rightness' in the way philosophers do. For my simple purposes here, I shall follow the more general usages of the psychologists.

4 To take a simple case, Amy Wrzesnienski, a psychologist of NYU, studied the happiness levels of hospital janitors who were charged with removing human waste (typically thought of as one of the least desirable positions, this job often involved cleaning urine and vomit from floors). Surprisingly, Wrzesnienski found many janitors of this category who reported they found their work extremely gratifying.
} 
possessing special knowledge (knowledge that they themselves only may possess), they will find themselves positioned so as to act on that knowledge, and to be appreciated and rewarded for the contribution they thus make.

If you imagine capitalist firms in the advanced economies of the Western democracies as organized along rigidly hierarchical, command-and-control models, then positive psychology would support skepticism about whether people would find their work meaningful in that environment. However, after Maslow, and through the competitive pressures resulting from firm diversity, many of the most successful firms systematically sought to reorganize the workplace so that workers might find personal meaning in their work.

Perhaps the most potent of these new management forms is 'Market-Based Management $^{\circledR}$, $\left(\mathrm{MBM}^{\circledR}\right)$. Pioneered by Charles Koch, MBM is founded upon the insight that, just as market-based institutions, information-sorters, incentive-structures, and personal values have demonstrated a superior capacity to generate wealth on a societal level, so too firms that can import market-based institutions and values in their internal management structures will be most successful over time (Koch 2007). MBM is relevant to market democracy not only because of its dramatic success as a management form. Just as important: MBM is the management style that most closely aligns with the recommendations of positive psychology.

For example, under command and control models, workers were typically directed to whatever tasks management deemed most important, which in practice often meant that workers were directed to 'overcome their weaknesses.' By contrast, MBM focuses on the idea of specialization through trial and error: the comparative advantage of workers is discovered by trying them in a variety of positions until managers discover which each does best. When making hiring decisions, the MBM approach looks first for talent and values, rather than running down an interview checklist seeking a 'fit' with specific management-defined personnel needs. Within MBM firms, employees are not hired to fit slots. Instead, they are hired for their virtues and talents and then directed to 'work to your strengths.'

Market-based societies use property rights to improve the use of knowledge and to provide incentives. MBM mirrors property rights with 'decision rights': clearly defined project-areas over which individuals and small teams are officially recognized as having decision-making power. Employee compensation is tied as closely as possible to actual output or performance (rather then job status or seniority). Individuals are rewarded based on the value they produce for the company, with no predetermined limits. Csikszentmihalyi's idea of flow, recall, is a kind of vital engagement which arising from immersion in tasks that people find at once challenging and yet suited to their own unique abilities. The structures of MBM seek to unleash the productive power of flow. MBM also routinely encourages workers to 'look through' the particular tasks they are performing, invoking them to see themselves as participants in the great social project of economic production, a project that over time can improve the lives of everybody. ${ }^{5}$

So now we see that market democracy, along with its steadfast commitment to maximizing the wealth of the least advantaged, also presents us with a distinctive

\footnotetext{
5 On this point, see especially Koch (2015).
} 
account of meaningful work. On the social democratic ideal of work, recall, workers are imagined as finding meaning in their work by focusing on their status relations as co-workers: work is meaningful to the degree that the workplace is democratic, with the voice of each carefully affirmed as morally equal to the voice of each of the others. This is an inward-looking, relational conception of meaningful work. By contrast, market democracy finds the meaningfulness of work in people's experience of agency. The focus is not people's positional-relation to their fellow workers, but on people's seeking out challenging tasks that absorb their attention. The task-absorption of market democratic work is explicitly production-related. Meaning is found not through reflecting on one's internal standing, but through one's unique contributions to the great social project of creating value for other people. In its ideal of meaningful work, market democracy again shows its moral superiority to social democracy.

Chris Pierson is skeptical of my claim that thick private economic liberty should be recognized as a basic liberty. After all, as Pierson points out, recognizing thick economic liberty effectively gives a 'veto' to citizens engaging in independent activities, protecting them from legislators and other groups of citizens who wish to impede their activities in pursuit of morally important goals such as equality of opportunity or the difference principle.

I defend thick economic liberty on a democratic ideal of responsible selfauthorship. Pierson finds this justification unpromising. The real test of economic liberties, he states, must be empirical or historical. The classical liberal tradition in which I situate my argument has a special relationship to the real world. Rival specifications of property ownership regimes, for example, stand or fall based on how they actually function in the world. Here Pierson saddles up David Hume, for whom, as Pierson reminds us, 'property was artificial, it was a societal creation (not a natural right) and its justification was that it worked.' Further, Pierson says, the only thing that can justify a given specification of property rights in the Humean system is the claim that that particular specification works (that is, that it proves itself functional towards given ends). Pierson claims that, because of its sole reliance on questions of functionality, Hume's view is rendered 'acutely vulnerable to an egalitarian reading.' Quoting Bentham, Pierson writes: 'The more nearly the actual proportion approaches to equality, the greater will be the total mass of happiness.'

Since writing Free Market Fairness, I have become increasingly interested in more fact-dependent, and indeed Humean, strategies for justifying the market democratic political settlement. Gerald Gaus's masterful work, The Order of Public Reason (2012), continues to reverberate across the intellectual landscape, challenging the entrenched defenders of public reason liberalism to look again at less idealized, 'Humean' common-interest approaches to political justification. Without here taking up Gaus's fascinating proposal, there is one very Humean response to Pierson that I cannot resist noting. Pierson, by way of marginal utility theory, shows how Benthamites might turn the Humean view in a robustly egalitarian direction. But, again, via the test of empirical and historical observation, we also find in Hume one of the strongest and most plausible arguments against egalitarianism. Hume writes: 'Render possessions ever so equal, men's different 
degrees of art, care, or industry will immediately break that equality. Or if you check these virtues, you will reduce society to the most extreme indigence; and instead of preventing want and beggar in a few, render it unavoidable to the whole community.' (Hume 2004, sect. III, pt. ii, p. 155). This logic runs deeper than the theory of marginal utility that Pierson, in the name of Bentham, trots out on behalf of material equality as a (functional?) social ideal. If we are to judge rival property systems by the empirical and historical facts, it seems beyond question that Hume's warnings against the schemes of perfect material equality must be taken as fixed points (or at least, as fixed as any historically-based point can be).

Pierson also seeks to pull me away from ideal theorizing and into the real world through a reconsideration of my Monopoly example. In $F M F$, I describe a series of Monopoly rules variations-Feudal, Classical Liberal, and High Liberal-to make vivid the High Liberal conviction that their ideal of substantive justice is a moral advancement over the earlier forms it displaced. If I understand Pierson's argument, he proposes that we consider Monopoly as an actual model for evaluating market society. Thus Pierson invites us "to think about playing Monopoly "in the real world.", Noting that Monopoly was invented by Lizzie Magie as a radical criticism of market society, Pierson correctly notes that " $\mathrm{t}]$ he game was designed to show how a series of "free and equal" exchanges between economic actors with unequal initial bundles of resources would tend to concentrate resources in the hands of an ever smaller elite.'

It is not difficult to point out the shortcomings of Monopoly as an analogue of market economies. With players rolling dice across a board of fixed options, the rules distort the idea of consumer choice, which is central to market economies. Rather than seeking out mutually advantageous interactions, Monopoly contestants interact when a dice roll lands them on properties owned by other players, with rules requiring players to pay 'rent' for no service (Powell 2004). There is no role for experiment and innovation. Instead of a dynamic system of interactions for mutual gain, parties interact as winners or losers, a brutal species of zero-sum logic that by game's end renders every player, but one, bankrupt.

I doubt that Pierson is serious in his suggestion that the game of Monopoly illuminates anything about the political economy of market democracy. But his use of this example brings us to the main point that I would like to make in response to Pierson's essay. It is true that defenders of classical liberal institutions have traditionally rested their case on consequentialist considerations. But in FMF I seek to remove the defense of classical liberal institution from its reliance on strictly empirical considerations. Instead, I show how a defense of classical liberalism might be conducted from the more principled foundations of public reason. As I put this point elsewhere: 'When our deliberations conclude, and the philosophers put on their coats and head home, the strongest arguments for classical liberal institutions turn out to be democratic ones.' (Tomasi 2013).

Richard Penny also criticizes my thesis that thick economic liberties should be recognized as basic rights. Penny focuses on the concept of self-respect, arguing that that I have not demonstrated a clear linkage between thick economic liberty and that core normative concept (interpreted in my market democratic way). Indeed, Penny argues that a recognition of thick economic liberty generates ancillary risks to self- 
respect (at least, to self-respect as properly understood). These risks would not arise within social democracy, with its affirmation of (merely) thin economic liberty as basic.

Self-respect is a bedrock concept within public reason. Penny's steady focus on that concept may explain why I find his discussion of $F M F$ exceptionally challenging. Still, I have already foreshadowed part of my reply to Penny's penetrating analysis. For example, like Clayton and Stevens, Penny reads FMF as arguing for thick economic liberty via a maximizing conception of self-respect. Again, I fear that some of my own formulations may have encouraged this reading. But as I note in my reply to Clayton and Stevens, my official position regarding the link between thick economic liberty and the moral powers of self-authorship is not maximizing but sufficientarian. So my market democratic conception of the moral powers of citizenship, and the ideal of self-respect, may be closer to the concept employed by the orthodox Rawlsians than Penny believes.

In a particularly illuminating section of his essay, Penny reminds us that Rawls at one place actually affirms a thick conception of economic liberty such as I defend, or at least, Rawls admits that a 'classical liberal' scheme of economic liberties might be justified by historical and social circumstances (Rawls 2001, p. 114). From this Penny, suggests that Rawls affirms a thin conception of such liberties as among the basic liberties more for methodological reasons than for normative ones. Rawls affirms a thin conception of economic liberty as basic because he hopes this minimal conception might provide a common starting point for public reason between parties who, on the one side, hope to fill in the details of property ownership (at lower levels of arguments) so as to include a private ownership of productive capital (capitalism) and those who, on the other side, hope to interpret the ownership of productive property in collective terms (socialism).

Penny has guided us to a difficult problem within the structure of public reason liberalism. At the most basic level, the very categories 'methodological' and 'normative' threaten to merge. This is because the drive to find a reasonable starting point for reasoned deliberation-which, in this context, is a hallmark of the 'methodological' - is itself an expression of our commitment to seek terms which citizens viewed as free and equal moral beings can accept-an expression of respect that is paradigmatically 'normative.'

However, I believe that public reason liberals must seek to maintain a distinction between the normative and the methodological even at this deep level. Indeed, Penny's fuller critique of thick economic liberty helps show why. As noted a moment ago, Penny believes that a thick conception of economic liberty generates ancillary threats to people's self-respect. There is an ambiguity in interpreting the status of these threats, since its not entirely clear what level of idealization Penny is operating at when he identifies these challenges to the market democratic view. However, so that he and I can engage, allow me to stipulate that my argument tracks up and down the levels of idealization so as to match whichever level Penny understands himself to be offering his objections. But then, surely, Penny would agree that socialist conceptions of ownership rights generate 'risks' to the selfrespect of citizens that are (at least) as dire as any Penny suggests may arise within market democracy. 
Recall that I am stipulating that my argument here should be read as traveling up and down levels of idealization so as to match whatever level of analysis Penny means to be launching his critique. Perhaps the familiar worries about how socialist ownership schemes generate risks to self-respect become less severe as we ascend further away from the facts in the direction of (realistically utopian) socialist ideals. But then the same is true of the risks generated by the capitalist ownership of market democracy. But if, as we move closer to the facts, Penny's warnings about the risks posed by capitalistic economic liberties begin to increase, then surely our concerns about the risks to self-respect under socialism increase by (at least) the same degree.

My point is not that Penny must choose between capitalism and socialism in pressing his critique. Rather, the problem is that anyone who, like Penny, would leave the choice of economic system to be made at later stages of argument, ipso facto leaves citizens vulnerable to the direct and explicit threats to economic selfauthorship that socialist political economy generates. In leaving citizens vulnerable in this way, it is no help at all to point out that, if rules outlawing citizens from owning private property or opening their own businesses are enacted, those laws 'will be the product of a critical mass of citizens engaging one another in a process of political deliberation and exercising their political liberties in order to pursue their preferred legislative outcomes'. A violation of a right is a violation of a right, and no majority of any size has standing to inflict rights violations.

For me, Penny's searching critique serves as reminder why we must seek to keep separate the methodological project from the normative one when we take up the problem of deciding what to include on the list of basic rights and liberties. Putting forth a set of basic liberties that affirms only a thin conception of economic liberty may indeed seem prudent from a methodological perspective. After all, that approach would render the democratic theory of justice 'neutral' with respect the question of socialism versus capitalism. But here our normative commitment to develop a vocabulary of reason that respects the moral powers of citizens is more fundamental than our aspiration to set the stage for social agreement, no matter the facts. After all, this is the level of argument where, uniquely, we are asked to determine which domains of independent activity are essential to our developing the powers we have as equally free and independent authors of our own lives.

Penny also raises a concern about my democratic interpretation of the Difference Principle. Penny sees a tension between my idea that people's self-respect depends in part on their seeing themselves as economic causes of their own lives and my idea that justice requires that we seek to maximize the wealth and income of the lowest paid class of workers. After all, Penny asks, if this scheme succeeds so that all citizens really do come to enjoy significant wealth and income, does not that very fact 'take the trouble out of life' in the sense of lessening their sense of agency?

In my response to Clayton and Stevens, I developed my market democratic interpretation of the Difference Principle by offering an account of market democracy's ideal of meaningful work. I hope that what I say there may dispel Penny's impression that market democracy values wealth for the sake of wealth. Instead, the greater wealth thesis refers to a dynamic process of productivity, a process that is constituted by the exercise of self-authorship in the economic domain — taking risks, failing and learning, pursuing goals and achieving them. Self- 
authorship is not something the economy 'spits out' as a product, the way social democratic programs (supposedly) 'spit out' a certain status for persons. Again borrowing terms from Amartya Sen, market democracy sees the achievement of greater social wealth, and the reduction of risk, as a comprehensive outcome rather than a culmination one. ${ }^{6}$

Daniel Layman accepts my thesis that economic liberties should be recognized as basic. However, Layman argues that these economic liberties, like the political liberties, must be protected at their fair value: 'states must guarantee that citizens of roughly similar dispositions and talents have a roughly similar chance of economic success'. A recognition of economic liberties as basic pushes in the direction of social democratic institutional forms rather then market democratic ones.

Layman's argument is ingenious. It gets its power from drawing our attention to some similarities between political and economic liberty. In the end, though, I think Layman overlooks differences between political and economic liberties that are significant enough to undo his proposal.

A main reason Rawls picks out the political liberties for special protection springs from the 'limited space' that is uniquely characteristic of the political domain. Indeed, for Rawls, this feature of political life explains why the capacity of people to exercise their political liberties (and so develop their moral powers) depends on contingencies of economic and social power (Rawls 2001, pp. 148-50). In politics, where specific decisions need to be taken, activities are channeled toward those decision-points, such that the greater influence of one person or group on that decision necessarily means lesser influence of others holding a different view. The other basic liberties lack this characteristic of political liberty. Certainly, one person's excising of an economic liberty (say, opening a pet grooming business) can impinge upon another person's exercising their economic liberties, just as one person's exercising liberty of conscience (say, by purchasing billboard space promoting a particular religious position) can impinge on other people's exercise of that liberty. However, unlike with the political liberties, the exercise of those other basic rights and liberties do not operate in a context that is zero-sum.

To make this vivid, consider Layman's third thesis: the degree to which citizens can effectively acquire property and use it according to their own conceptions of the good depends on their economic power in relation to others. Now, interpreted in a weak way, a similar claim might just as well be made about the exercise of other basic liberties, such as freedom of expression or association. The stronger interpretation, which Layman would need to bring this thesis about the conditions of the exercise of economic liberty in line with those of political liberty, would require showing that the economic domain has limited space, and that these limitations are of a sort that that is simultaneously analogous to political liberty and dis-analogous to any of the other basic liberties.

To support this, Layman offers a thought experiment. Andy, who has inherited a fortune, opens a chain of gleaming pet-grooming spas. Meanwhile, Amy, with no

\footnotetext{
${ }^{6}$ For my discussion of Sen's distinction between culmination and comprehensive outcomes, see Tomasi (2012), p. 183. In this part of my reply to Penny, I am especially indebted to Nicholas Geiser. I borrow some of the wording in this paragraph directly from him.
} 
family support, is scrimping and saving in the hope of someday opening a pet grooming shop of her own (Amy's Pup-in-the-Tub). But while Amy works and saves and dreams, Andy has cornered the market, dashing Amy's hope. Layman says the competition between Amy and Andy is unfair. Andy's deploying his greater financial resources so as to make his chain of stores superior to any shop that Amy might open is analogous to using physical force. Further, with his great resources, Andy can hinder Amy's economic ambitions no matter what other market Amy might decide to enter. The competition is rigged in Andy's favor. Even without making Amy's economic liberties worthless, Andy thus can make her liberties less valuable in a way that is unjust.

I am not persuaded that Layman's example of Andy brings the economic liberties into line with the political liberties in a way that would make us see both classes of liberties requiring protection at their fair value. Layman suggests that Andy has reduced the value of Amy's economic liberty. But notice, first, that this is not quite right: it is the pet owners who through their choices generate this reduction (if anyone does). Further, Layman's idea that Andy can reduce the value of Amy's economic liberties across all markets relies on an understanding of market society that I find odd. In real markets, the people who have capital are typically not the same people who have entrepreneurial knowledge. So there is no reason to think that people with lots of capital can block competitors who have less (or none).

More significantly, the 'space' of markets is decidedly not limited in the way that an argument such as Layman's requires it to be. I composed most of FMF in a coffee house in the town of Warren, Rhode Island. While I was working on my book, someone opened a small pet shop next door and called it 'Amy's Pup-in-theTub.' That real shop inspired the example in my book. About a year ago, Amy's Pup-in-the-Tub suddenly closed. The store stood empty for several months. Finally, someone else rented the space, and it is now a thriving yoga and pilates studio.

Did Amy close her shop because she was forced out of business (say, by some gleaming chain of pet spas)? I do not know. But when Amy's Pup-in-the-Tub closed, a new opportunity opened for someone else to pursue a dream. I will not here rehearse lessons about how prices convey information that allow productive resources constantly to be routed and rerouted to more highly demanded uses in a market economy, with entrepreneurs upending the status quo only to find themselves upended in turn. Instead, I will simply say this: the competition within markets is fundamentally unlike the competition we see in political campaigns. Instead of a run up and convergence into discrete moments of vote, market competition is a fluid process. By its very nature, the 'space' in which market competition occurs is more dynamic and porous than static and closed. Threats to the value of political liberty are different in kind from threats to the value of economic liberty.

Finally, I turn to the elegant and thoughtful essay by Steven Lukes. Lukes objects to my use of the category 'social democracy,' arguing that label is more aptly reserved for the historical institutional forms of European democracies, which are more properly described as welfare states than any of the ideal forms of social democracy discussed by philosophers (property owning democracy and liberal socialism). I agree that actual European democracies, such as Sweden, Germany, 
France, Spain, and Greece are welfare states, rather than as meeting the standards of any of Rawls's ideal regime types. By the same token, the United States is also most accurately described as a welfare state, rather than as meeting the high moral requirements of any of my idealized forms of market democracy (democratic limited government and democratic laissez-faire). So I use social democracy, like market democracy, as terms of art. I use those terms to point to rival visions of the moral requirements of democratic living together. My point is not that one type of historically existing welfare state, (say, the United States) is better than any other existing welfare state (say, Spain). Rather, my hope is to invite people to look up at the sky with me. When we do, we find the moral constellation that I call market democracy. When real democracies look for stars to guide democratic citizens as they steer their societies in the direction of justice, it is that constellation we should focus our wishes upon, not the constellation of social democracy.

Lukes also expresses skepticism about whether any of my market democratic forms can actually realize the difference principle (even granting, as I read him, that we interpret that principle in market democracy's wealth-focused terms). He notes the environmental challenges that face growth-oriented societies, and also doubts that the remarkable growth that we have seen in market-oriented societies can continue. But, of course, my argument that market democracies 'realize' the difference principle (and the many other daunting moral requirements of free market fairness) is an idealized one: I am merely seeking to identify which form of democracy is most just, if we could achieve it. The prognostications that Lukes makes about the coming environmental collapse and the end of economic growth are simply that: prognostications. I do not see how we can adjudicate such complex empirical questions from here. So, on the empirical point, I simply note that growth skeptics, from Robert Malthus to Paul Ehrlich to Robert Gordon, have a poor track record. The burden is on them to show why 'this time is different.' On the moral point, the movements toward economic liberalization that we have witnessed in places like China and India have given millions of people the chance, for the first time in their lives, to lift themselves up away from grinding poverty. Because of liberalization, our generation has witness the greatest decline in global economic inequality that the world has ever seen. Surely, this great change should give a humanist such as Steven Lukes reason to pause, even if he is not ready quite yet to break into applause.

More profoundly, Lukes raises a worry about the form of life that is denoted by the rise of market democracy. Lukes quotes me: 'social democracies seek to decommodify society in the hope of politicizing it; market democracies seek to depoliticize social life by commodifying it' (Lukes, quoting Tomasi 2012, p. 232).

On the immediate issue of commodification, I suppose that I see this issue differently than Lukes (and others, such as Michael Sandel, who have recently sounded alarms, both aesthetic and moral, about what they see as the growing commodification of our world) (Sandel 2012). Channeling Wordsworth, Coleridge and (perhaps unfortunately Thomas Carlyle, the racist critic of classical economics), Lukes worries that the coming of market society corrupts our souls, with cold calculations displacing the more subtle, beautiful, and lovely feelings of which we 
humans are capable. ${ }^{7}$ I am sensitive to the concerns that Lukes pens so eloquently here. In the end, however, I doubt that commodification is the bête noir that Lukes means to be targeting. As Brennan and Jaworski (2015) persuasively argue, buying and selling does not itself introduce wrongness: if people may do certain things for free, for example, then there is no added wrong in their doing those things through a market. I agree.

Still, whether analysis of commodification we come down on, I believe that Lukes is reaching toward a deeper issue when he raises this concern. When I wrote that market democracy seeks to commodify the world while social democracy seeks to politicize, my intention was to draw attention to a fundamental difference between the social democratic and the market democratic visions of human living together. In response to Luke's worry about the marketization of our world, let me say something about this contrast of visions.

As an ideal, politicization seeks to expand the domains of our lives in which the best we can hope for is to rule others, and to be ruled by them in turn. This ideal assumes that people share, or can be brought to share, a set of common values, purposes or ends across each of the domain that they aspire to politicize. On this approach, people are then encouraged to bind themselves together, or to imagine themselves so bound, in the hope that those shared purposes might be achieved through their collective deliberations and actions. Individuals are urged to take the steel bit of 'ruling and being ruled' as a requirement of achieving those shared purposes. In the social democratic ideal, this is true at the level of state action, the community, and within the workplace too.

By contrast, market democracy, through its emphasis on commodification, brings our attention to a certain activity of coordination. The focus is on the microinteractions of individual citizens, with all their diversity of dreams and ends, rather than the collective pursuit of some (allegedly) common value identified by a General Will. The primary shapers of a market democratic world are not intellectuals sitting in their armchairs but ordinary people going about their business, each of them desiring, creating, buying, selling, trading, and changing their course of direction whensoever they please. Within the market democratic ideal, as Adam Ferguson put it, social order arises 'as the result of human action, but not the execution of any human design' (Ferguson 1782).

There is a Greek word, katalattien, which means 'to exchange.' Like many Greek words, this word carries within it more subtle meanings. Katalattien also means 'to become reconciled with,' or 'to admit one into the community.' Getting still closer to the market democratic ideal of human living-together, katalattien also means 'to change from an enemy into a friend.'

This is a special form of friendship. It is not an exclusive ideal, say, like a friendship between two people who discover that they share common interests or values and who come together in recognition of that fact. Nor does this ideal of friendship require proximity — whether across a dimension of kinship, culture, religion, or territorial space. This form of friendship does not require that people

\footnotetext{
7 Carlyle's racism is not incidental to his rejection of the (egalitarian, preference-respecting) ideas of the classical liberal economists. See Levy (2002).
} 
intentionally, or even knowingly, provide benefits to their market made friends. Rather, on this ideal of living-together, diversity is celebrated chiefly because, through voluntary market exchanges, the actions of each have the potential to improve the chances of all. People become bound together as friends not in a judgmental way, but in the indirect and thus less demanding sense of having become mutual benefactors to one another.

Not everyone would celebrate the spread of this market-based form of human interaction. There are cultural conservatives, Romantic poets, and, I admit, wise and good-hearted people such as Steven Lukes who may reflexively recoil at our world being remade in along these 'katallactic' lines. Many might consider such a transformation not merely unlovely, but undemocratic too.

Such a reaction would be doubly mistaken. Democracy, indeed, is a form of friendship. But friendship can take more than one form. More precisely, there is more than one interpretation of how citizens might best live together as free, equal and independent authors of their own lives. Respect for the freedom and equality of our fellow citizens, the most strong as well as the most weak, does not direct us to ever-expand the domain of the political. Sometimes, indeed more often than not, the respect we have for our fellow citizens directs us to reserve space in our world for market-based forms of friendship. Carving out and protecting such space, above all else, is what the market democratic research program seeks to do. In the face of all the concerns laid out in this symposium, I find that market democratic ambition lovely still.

Acknowledgments I thank the editors of Res Publica, and especially David Stevens, for organizing this symposium on Free Market Fairness. I am grateful to the members of the Market Democracy Working Group within the Political Theory Project at Brown University, especially Dan D'Amico and Nicholas Geiser.

Open Access This article is distributed under the terms of the Creative Commons Attribution 4.0 International License (http://creativecommons.org/licenses/by/4.0/), which permits unrestricted use, distribution, and reproduction in any medium, provided you give appropriate credit to the original author(s) and the source, provide a link to the Creative Commons license, and indicate if changes were made.

\section{References}

Brennan, Jason. 2012. The ethics of voting. Princeton, NJ: Princeton University Press.

Brennan, Jason, and Peter Jaworski. 2015. Markets without limits: Moral virtues and commercial interests. New York: Routledge.

Caplan, Bryan. 2007. The myth of the rational voter: Why democracies choose bad policies. Princeton, NJ: Princeton University Press.

Csikszentmihalyi, Mihalyi. 1997. Finding flow: The psychology of engagement with everyday life. New York: Basic Books.

Coase, Ronald. 1937. The nature of the firm. Economica 4: 386-405.

Ferguson, Adam. 1782. An essay on the history of civil society, 5th edn. London, T. Cadell. http://oll. libertyfund.org/titles/1428. Accessed 11 Aug 2015.

Gaus, Gerald. 2012. The order of public reason. Cambridge: Cambridge University Press.

Haidt, Jonathan. 2006. The happiness hypothesis: Finding modern truth in ancient wisdom, 2006. New York: Basic Books. 
Hume, David. 2004. An enquiry concerning the principles of morals, 2004. Whitefish, MT: Kessinger Publishing.

Koch, Charles. 2007. The science of success: How market-based management built the world's largest private company. Hoboken, NJ: Wiley.

Koch, Charles. 2015. Good profit: How creating value for others built one of the world's most successful companies. New York: Crown Business.

Levy, David. 2002. How the dismal science got its name: classical economics and the UR-text of racial politics. Ann Arbor, MI: The University of Michigan Press.

Maslow, Abraham. 1965. Maslow on management. New York, R.D: Irwin.

Murphy, Liam, and Thomas Nagel. 2004. The myth of ownership: Taxes and justice. Oxford: Oxford University Press USA.

Powell, Benjamin. 2004. What's wrong with Monopoly (the game)? Mises daily (Mises.org/library/ whats-wrong-monopoly-game), February 13.

Rawls, John. 2001. Justice as fairness: A restatement. Cambridge, MA: Harvard University Press.

Sandel, Michael. 2012. What money can't buy: The moral limits of markets. New York: Farrar, Straus and Giroux.

Tomasi, John. 2012. Free market fairness. Princeton: Princeton University Press.

Tomasi, John. 2013. Market democracy rising: Reply to Berman, Levy, MacGilvray, and Taylor. In Symposium on Free Market Fairness. The Journal of Politics, 75, 1-4.

van Parijs, Phillipe. 2003. Difference principles. In The Cambridge companion to Rawls, ed. Samuel Freeman, 200-240. New York: Cambridge University Press.

von Platz, Jeppe. 2013. Are economic liberties basic rights? Politics, Philosophy \& Economics 13: 23-44. 